Pakistan Journal of Humanities and Social Sciences

January - March 2019, Volume 7, No. 1, Pages 45 - 61

\title{
Innovative Temporary Retailing in Fashion Involvement: Analyzing Youngsters Buying Behavior towards Pop-up Fashion Stores
}

\author{
Ujala Ehsan ${ }^{1}$, Hafiz Fawad Ali ${ }^{2}$, Rabia Shahid ${ }^{3}$ \\ ${ }^{1,2}$ Institute of Business Administration, University of the Punjab, Lahore \\ ${ }^{3}$ Hailey College of Commerce, University of the Punjab, Lahore
}

Email: ujalaehsan1995@yahoo.com

\begin{abstract}
The motivation behind this quantitative research was to break down three goals: (1) the effect of adolescents form contribution with measurements of fashion awareness and fashion involvement, (2) the effect of youth's state of mind towards pop-up stores and (3) the effect of youths purchasing conduct towards pop-up retail locations. The scope of the study is limited to adolescent/youth studying in different departments of the University of the Punjab, Lahore. The sample of this study was 339 self-controlled questionnaire which was gathered from five departments of Punjab University Lahore, Pakistan. SEM method was used to analyze the information made in the examination. IBM SPSS-22 and AMOS two statistical software's were used in this investigation. The present research uncovered that fashion involvement and adolescents purchasing are not related. Behavior towards pop up stores totally intervened the connection between fashion involvement and youths purchasing pattern.The current study has some limitations in that it used non-probability sampling technique and a smaller sample size due to limited resources and time. The data was collected from the students of University of the Punjab only. Future researches may address these limitations and further validate the findings of this study by using a larger sample size and a more suitable probability sampling technique.
\end{abstract}

Keywords: Pop-up Retail Stores, Fashion Involvement, Attitude, Youngsters Buying Behavior

\section{Introduction}

TCEBR (2015), was characterized pop up more determinedly such as a transitory plant, transitory slow down of the merchandise and ventures for the transitory timeframe era and furthermore mentioned that it may possibly something since road food dealers towards design stores, edibles teashops, and so on. DCLGATCM (2013), very much characterized that a genuine popup supplies" backbone utilize an unfilled or current planetary, it partakes 
obviously obvious its introductory and last date, the objective of popup provisions isn't for strength, all consider to be energetic and can possibly change to a diverse places and be in around refined, contrary and extraordinary. In the year 2013, DCLGATCM characterized a constrained method of popup provisions that it requested the pop store, not a commercial center and neither a diminished departmental provision. Trade manufacturing has isolated into 2 assorted commercial center commitment which is part advertise (endless shop) and controlled marketplace. Disjointed bazaar affection person's strategies through which customers purchase things in the previous after the resident commercial center, the situation contains the cost consulting among the merchant and buyers. Then again, the prepared platform is positive as requiring gathering, the attainable quality of the properties not guaranteed and much of the time products are one of a kind in the sorted out market, charges are additional factors and the standard is clearly adjacent popular the merchandise (CocaCola RRC, 2010). The trade business slants devise not ever persisted steadily by way of the situation, method of consistent development besides extension for the most part since the last time frame, in the territory of information and development awareness of web utilization and online networking deviations the retail business as well as modified the purchaser shopping conduct outline and the advancement of internet business retail industry built up an extremely unremarkable commercial center (Grewal, Roggeveen, \& Nordfalt, 2017). PUS is likewise called a practical transaction. The situation is additionally clear and a measure of supposed the customer conduct partakes familiar mostly and these days customers are watching for charming spending encounters through their spending execution (Chen \& Fiore, 2017; Niehm, Fiore, Jeong, \& Kim, 2007). Popup is imaginative and organizing trade showcasing practice, fashionable nowadays purchaser utilize adjusted items and organizations keeping in mind the end goal to pick either the sort of merchandise appropriate standing to customers' essentials and presences (Chen \& Fiore, 2017). According to Wallace (2016), 72\% of customers accept goods from stocks and furthermore watching aimed at reputable instore enhancement. The around populace trendy Pakistan is 196 million, trade relevant trendy Pakistan continually rising then adjusting happening the situation of excitement and differing presences of buyers in the nation. Presently days the total claim and offer concerning popup design goods isn't just incredible in different nations yet additionally in Pakistan. Future sign begins that PUS existed additionally consolidated through the youthful age, which stayed likewise called adolescents. The alteration in the design exchange was huger in city parts wherever the superstores exist to a great degree engaged in urban communities like Karachi, Lahore, and 
Islamabad. Popup in Pakistan recommendation picked elements and the growth are not in the least degree mindful. The study explores and established upon association that looking at adolescents purchasing conduct towards pop up form retail places. The independent variable of this investigation was fashion Involvement, and between was attitude and youths purchasing conduct was the dependent variable.

\section{Figure 1:}

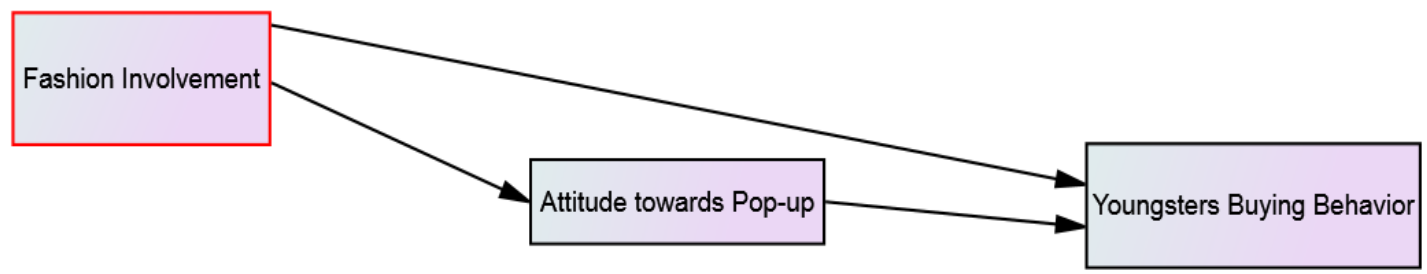

H1. FI has a connection with ATPUS.

H2. ATPUS has a connection with YBB.

H3. FI has a connection on YBB.

Fashion can be portrayed as a strategy of acknowledged the quick execution by an apparent element of individuals from a shared gathering of individuals since that execution they selected is flawless as a casually recognized for a specific time presence and confusion (Akyol, 2010). It additionally uncovered the social acknowledgment or social program when another polish and way keep running from its improvement to group intelligence and group conformity (Sproles, 1986). The contribution is a consideration and energy forced for the inspiration prescribed through a thing and condition that is theoretical by way of actually critical (Zhang \& Kim, 2013).

FI is a significant portion of the revolution that was distributed happening a civilization. Rogers (1983), labeled that fresh group are the leading instigators of the scientific invention they were an improvement and continue the shared position happening the culture, they preserve and in touch after the style so they care as for style originators trendy the humanity. In the future investigation, adolescents and central rivulet collections of individuals accepted the technical pioneering style (Bala, 2008). Theoretically, a general FI range can remain well-defined as it is founded on and belongings of fashion interactive doings. King \& Sproles (1973), hypothetical founded on preceding style investigation, here are on minimum 5 scopes of FI which existed, 


\section{A. Form creativity \& period of procurement}

The measurement established continuously essential prior collections and person buyers who were researching to the getting on acquiring and acknowledge the design, and furthermore the ancient elegance clients.

\section{B. Form in place of a relational correspondence}

The measurement, person's purchasers remain confounded who consume active and effective of the overwhelming inhabitants and they remain included to transmission the strong evidence to others.

\section{Style fascinated customers}

The estimation coming to after the clients who are exceptionally concerned and form worried about customers. In this range, purchasers are sufficiently integrated into the new form.

\section{Form training}

This scope of form association reaching out from those buyers who are constantly very much educated about the style which by and by effective in the market, these sort of clients are additional chic and in vogue and have mindfulness about the design field.

\section{E. Design mindfulness and reactions to altering the style patterns}

In the range, running from those clients who forcefully answer and watching the different and fashionable inclinations and they are completely non-mindful since the others. PUS produces the possibility aimed at unimportant businesspersons and design inventors who are self-representing and they progressing their individual particular trade set-up of moderate form and afterward they took those events, they generate the elite worth relational words and they executed it into discount plan of action (Alexander and Bain, 2016; Cataldi et al. 2010; Clark, 2008; Fletcher 2010; Pomodoro, 2013; Osswald and Ziehl, 2015). Now the popup style very much characterized as the situation was a form trendy dress and presence stocks that are close-by formed and re-utilized. A measure of a more extensive conclusion, popup design is an offer of consultation of form goods which are viable in the consideration of clients (Clark, 2008). The new form of the situation strength and separate design interest is a huge offer of popup technique trade locations.

\section{F. Adolescents style modernizers}

In the former investigation (Goldsmith et al., 1996) created that youths design pioneers reflected themselves an extra enthusiastic, tolerant, present day, concurred, fascinating, principal, unsuccessful as related to other fashion assemblies. 
Pakistan Journal of Humanities and Social Sciences, 7(1), 2019

Form garments scholars take ceaselessly dedicated surprising reflection to persistent the conduct of adolescents since they are fashion modernizers. The examination about design pioneers and adolescents form inclusion are similarly broad (Sproles, 1985), it securities esteems, demeanor, execution, and every single other impact that involved in the fashion communicate how fashion modernizer consider about their own particular self. For instance, a few examinations displayed that design ingenuity associated with self-introduction motivation, mindfulness, energetic and introduction (Gordon, 2004). This commonplace of design dress examination is exceptionally huge and fitting for the showing of self-appearance rationality. Form, elusively cautious as trendy apparel clothing, frequently it shows an essential utilization part of the consideration for the youthful clients. The greater part of the prior writing on design commitment is beside individual or excessively common in condition, making it impossible to be of genuine esteem. The vast majority of the ladies are very little worried about new elegances and these ladies are more frightened with what their dress says in regards to them. Be that as it may, the majority of the ladies are fashion inclining nowadays and worried in sharp and upscale dress and other originator matters, this new sign is just informative and can't from a procedural illumination about design conduct. The sign from the experimental examination give a more unmistakable perspective of adolescent propelled design conduct. Self-expression. The total zone of self-expression conditions to the gathering of strategies and states of mind that free grasp to themselves. Self-expression incorporates self-respect, or valuation and preparing with which a solitary assessments him or herself. Self-articulation likewise incorporates self-idea, and responsiveness about form that people take off and anything that is comparable in the commercial center. Self-data. Self-learning is an information and information that recognizable has around the effects (Solomon, 1996). Self-learning is tremendous since it contributes information about self-perception and spur the immediate, it gives chief and way to deal with assemble obvious exercises (Malhotra, 1988). Young customers regularly obtainment the stock that is vague with their charactersand upgrades their authentic and flawless self-thought (Malhotra, 1988; Onkvisit and Shaw, 1987).In this examination, a state of mind portrayed as a person's by and large valuation towards pop up design retail locations is called as disposition (Fishbein and Ajzen, 1975). For accomplishment the more profound data about the impacts that boost Youngsters states of mind and behavioral reason towards pop up form retail locations. To get the proof 
about the youth's administration styles may help advertisers to recognize that purchasers who are awesome to rundown to a great degree planned buyers and amazingly changed shoppers.

By loyal the clients state of mind and basic leadership charms, sellers can just control the particulars of customers' slants and needs of divergent purchasers' and it likewise casual to arrange the differed clients' needs and thought to professionally for act and execution of choices made by clients' in the commercial center (Burns, 2011).

From this examination, Sproles and Kendall distinguished eight shoppers basic leadership and their disposition styles: which were;

\section{G. Perfectionist/brilliant mindful}

A buyer or youthful age aggregate putting to seek after out the most extreme greatness foodstuffs and workplaces.

\section{H. Brand mindfulness/value meets perfection}

A customer's or young people putting an arrangement to buy the greatness and excessive understood brands. These sort of clients are relied upon to think that exceptional worth by assets more prominent perfection.

\section{J. Development and style are conscious}

A customer or youth putting and plan to discover new and mechanical innovative products and expand joy and goal from searching for new and organizing merchandise.

\section{K. Engaging and shopping mindful}

A purchaser or adolescents putting to discover and consider shopping as an agreeable development and shops similarly as a diverting and want.

\section{Cost-conscious/esteem for the cash}

A buyer or youth disposition to requirement at the business circulation costs and want to buy limited time value products in general.

\section{Impulsiveness/negligent}

A purchaser or youth putting to purchase the goods at the branch of that instant and looks undisturbed around the amount he or she commits on spending or near getting the finest purchase.

\section{N. Confounded by ended decision}

A buyer whois dependably confounds that here are excessively varieties and promoting supplies as of which they purchase and select the merchandise and these are the 
customers who are conceivable a lot of contributions and have proven over-burden in the unassuming secured advertise.

These were the accompanying behaviors which were pondered in the first examines. In the present research ponder, the general state of mind is requesting to look at of adolescents purchasing conduct ATPUS.

Adolescent appearance is similar to be a supreme informally conscious group from the previous fifty years (Meister \& Willyerd, 2010). Alongside with the adolescent plentiful expenses on spending alignment, adolescents also choose innovative spending involvement. Adolescents were raised through that age anywhere spending was measured gone from impartial a humble performance of obtaining (Kol \& Lissitsa, 2016). In the development of trade manufacturing such as observed transaction and have abundant invention changes, and the fresh age group can change their spending elegances (Bakewell \& Mitchell, 2003). Adolescent ponders spending to be a basis and procedure of performing, so generally, they choose the new expenditure experience and they also wish an experimental marketing atmosphere (Kol \& Lissitsa, 2016). Adolescents are related and allied with the entertaining shopping and retailers interest the adolescent with different and creative marketing struggles and merchants also wonder the adolescents by given that exceptional and suggestion new things through the enjoyable situation (Huffelen, 2016). An indication through the reading that the metropolitan resident's organization attentive on shopping favorites of the adolescents originate that $70 \%$ of the women and $50 \%$ of the men are measured that spending to be a method of performing (Krueger, 2005).

There are succeeding impacts like a social, business and innovative headway altogether motivation to spending conduct and contributions (Bakewell and Mitchell, 2003). Adolescents are the age bunches they supported active at the season of innovation movement and globalization, disturb budget and the universe of unrest (McColl, 2013). The preservationist shopping plan "one size fits all" these sort of advertising approaches are not occur in the youthful age bunches in these days (Ferreri, 2016). Youthful gathering was conceived in the advanced world time frame, which in the long run and significantly slanted their expectations for everyday comforts and the way they assumed the proof. Mechanical unrest has been a necessity for the youthful age gathering and has skilled their alive presences with an adequately of data and basically passageway of data. Youths likewise grade to be to a great degree refined (Pokrywczynski and Wolburg, 2001) and calling eager. They have genuinely worth of training and reflect it a standout amongst other noteworthy income for 
accomplishment (Brosdahl and Carpenter, 2011). Youthful age has looked with high purchasing conduct impact than the additional ancient gatherings (Cui et al., 2003). According to Martin \& Turley (2004), By way of they are relied upon to impact shared expenditure, with the awesome extent of picked besides acquiring conduct to design things. As it were, youthful age is all the more searching for important items and more chic presence, which are music, sustenance ingestion and attire utilization (Morton, 2002). There are the youthful buyers buying conduct have definitively have a critical part as form trend-setters (Beaudoin et al., 1998). As indicated by Zhang et al. (2013), every so often youthful customers want to buy marked things and marked array at top of the line division's retail locations and periodically at office retail locations. Thusly, the name of the brands essentially exasperate the youthful purchaser purchasing conduct towards mold things, and they are masterminded to pay the top of the line cost for that particular agreeable brands that make the peaks and cleanness (Grant and Stephen, 2005).

\section{Methodology}

Cross-sectional review strategy and quantitative research approach have been utilized for social occasion information done independently from anyone else directed poll ponder from the respondents of administration sciences divisions/Institutes of Punjab University Lahore Pakistan. The entire populace of this examination was 2800 understudies. As indicated by (Krejcie \&Morgan, 1970) uncertainty the aggregate populace is 2800 , the example proportions will exist 338 contributors. The focused on the test of examination think about were singular bunches mutually the man and woman understudies. The goal aimed at coordinating just the understudies fashionable the subside and flow look into pondering is on the grounds that their purchasing conduct and disposition towards popup design stores through these endless time periods as of now.

What's more, the following autonomous variable design association was honorable and the figuring instrument of this variable utilized as a part of (Ryu, 2011) and this variable contained 9 things with two measurements form information and fashion inclusion. The needy variable was adolescent purchasing conduct which was stately by (Niehm, 2007) included 6 things. 5-guides Likert Scale was utilized toward reaction the objects of the poll.

IBM SPSS 22 and AMOS 22 these two programming has been utilized for investigating the information of this present examination. Illustrative examination of socioeconomics, unwavering quality investigation of factors and multivariate presumptions of decline has been inspected by utilizing IBM SPSS variant 22. CFA of separate factor and 
general factors, Measurement Model, SEM has been exploring by utilizing AMOS 22. Unwavering quality test and Validity examination were additionally finished by utilizing AMOS and utilizing exceed expectations for the last aftereffects of the concurrent legitimacy investigation.

150 male respondents and 188 female individuals. Two hundred and eleven of the individuals remained collapse between the stage of development choices of 20-24, 95 individuals remained collapse between the age extents of 15-19, 24 individuals were falling inside the age extents of 25-27, and eight individuals remained collapse inside the age extents of 28 or more. 307 individuals from the present examination were single marital status, 31 individuals from this examination were connected. 128 individuals were in professional education holder, 111 individuals stood MDH, eighty-five individuals stood GDH, and 12 individuals stood MSDH. 141 individuals are present fromthe institute of business administration, fifty-three individualsare present from the institute of administrative sciences and Institute of business and information technology, 52 individuals be present from Economics, and thirty-nine individuals existed from IM division. 215 individuals existed from NFS and 123 participants existed from JFS in the present research consider over. 224 individuals from the present examination were from the urban family establishment, 72 individuals were from the provincial family establishment, and 42 individuals were from a sub-urban family foundation. The mean estimation of enlightening measurements go between 3.19 to 3.45 , which demonstrates that the greatest of the reactions of this present investigation collapse amongst 'Unbiased' and agree by utilizing the 5. Likert scale. All the significance of Z-Skewness and Z-kurtosis of entirely factor fall between $-3.29<Z<+3.29$ that illustrations the information has ordinarily circulated. Fluctuation homogeneity assigned that $\mathrm{P}$ estimation of all factor of this examination are more noteworthy than 0.05 , that characterized the presumption of dependability of change has been met. In introduce examine contemplate the estimation of resistance and (VIF), everything was more noteworthy the base standard hence the circumstance has been happened. Congruity factor investigation of form contribution expressed that every one of the things have factor stacking more noteworthy than .3 hence no esteem will be excluded from this figure of Conformity factor examination of HSE, the Standards of similarity factor investigation has been happened. Congruity factor examination of (ATPU) signs that every one of the things estimation of factor stacking more noteworthy than .3. Similarity factor examination of youths purchasing conduct factor stacking have above than the estimation of .3. Congruity factor examination model for each factor thought 
as a solid match. Every one of the qualities in GFI, CFI, RMR, and RMSEA were higher the base criteria that determine the solid match show.

\section{Figure 2}

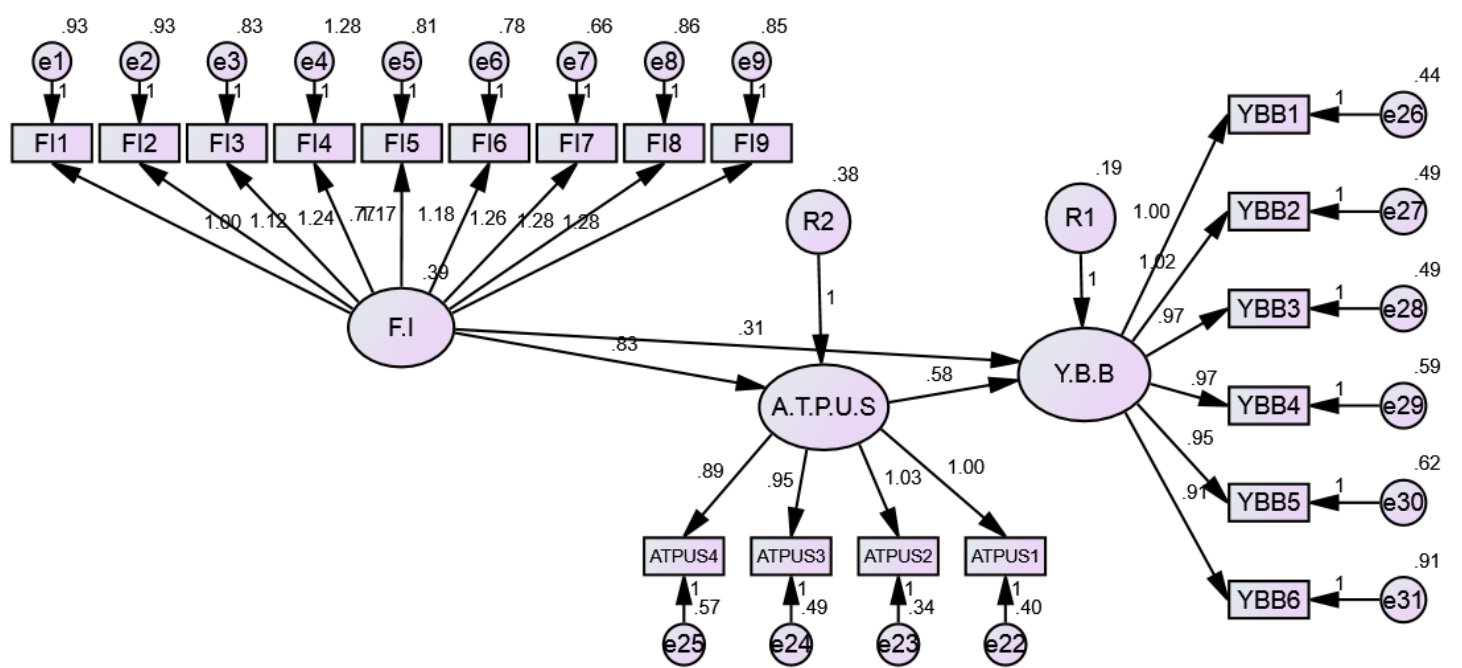

Joined legitimacy was stately by utilizing the normal fluctuation removed (AVE). The estimation of normal fluctuation extricated was .5 or higher than .5 with the goal that shows best focalized legitimacy between the things of factors (Hair et al., 2010). The estimation of normal fluctuation separated of mold contribution was .59, Attitude towards Pop-Up was .75, and Youngsters purchasing conduct was .69. Normal difference removed of factors were above than .5 so it signs great concurrent legitimacy of factors.

The unwavering quality test shows that Cronbach Alpha of mold inclusion FI, ATPU and YBB that was above than 0.5 which signs more prominent interior dependability of things of the poll in the present research think about. Composite unwavering quality shows the estimation of $\mathrm{CR}$ of the considerable number of factors was higher than .7 which demonstrated great composite dependability.

\section{A. Structural Model}

\section{Figure 3}

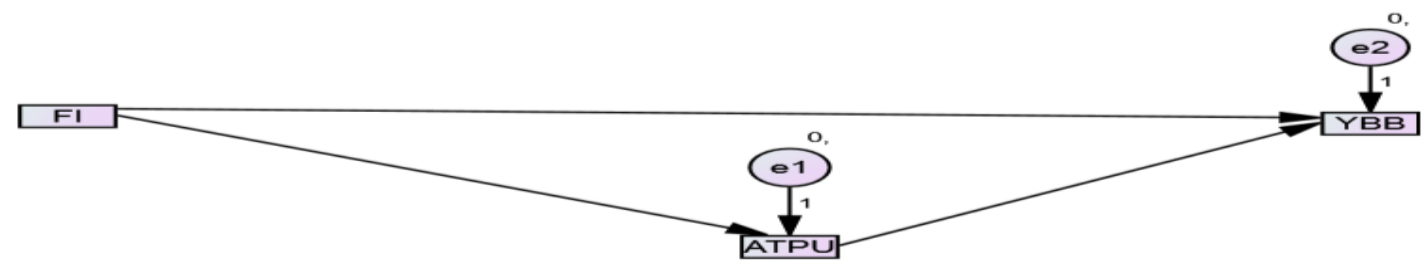


$\mathbf{H}_{1} \quad$ Fashion Involvement has a positive relationship with Attitude towards Pop-up stores

Fashion involvement was not essentially connected to the state of mind towards pop up stores as p-esteem might have been .102 more prominent than .05 . In this way, it was resolved that design association can't produce a state of mind towards PUS.

$\mathbf{H}_{2}$ : $\quad$ ATPUS has an affirmative association with YBB

The results determined the positive relationship of disposition towards pop up store to adolescents purchasing conduct. As p-esteem seemed to be .000 is under .05 besides constant esteem is .299 it uncovered that the optimistic huge association. By way of the state of mind towards PUS increments through the particular unit at that time youths purchasing conduct is relied upon to increment by .299 components.

$\mathbf{H}_{3}$ : $\quad$ FI has a positive association with YBB

Fashion involvement was not fundamentally interrelated to adolescents purchasing conduct. As p-esteem seemed to be .381 higher than .05 . Consequently, it is resolved that form association can't produce youths purchasing conduct.

\section{Managerial Implication and Recommendation}

The present research added a vital part to the present writing of the pop-up form stores and advantages to well perceive the youth purchasing conduct from their state of mind. The realistic qualities of research ponder additionally covering the prior work extensively and not-altogether from states of mind. The present investigation has critical ramifications for the retailers, promoting pros and superiors. This examination may be useful to retailers, it may be significant to perceive the adolescents purchasing conduct and behavior to pop up stores. By in perspective of the consequences of this investigation, it will likewise imperative thought for the organizations to rehearse this imaginative promoting strategy in heading to extension aggressive advantage in the to a great degree focused commercial center.

The future examination can be coordinated in other age people like seniors, experts and so on moreover, this exploration study should likewise be possible by other intervening parts of socioeconomics, for example, age, family foundation, pay and so on. this examination is established on quantitative and unmistakable in nature, the future specialist can likewise hone this investigation through subjective technique popular to get far-reaching accommodating of customer purchasing conduct towards pop up stores. 


\section{Conclusion}

Retailing part has new enlightened a portion of the progressed automated change and client information towards the brands. This present examination was established on organizing showcasing procedure that was pop up stores and looking at the youths purchasing conduct with interceding part of their disposition. In this manner, the discoveries of the examination think about established that, fashion association has non-noteworthy and not mediating the connection between the adolescent's states of mind. State of mind towards pop up stores has negative and not mediating the connection between youths purchasing conduct. 
Pakistan Journal of Humanities and Social Sciences, 7(1), 2019

\section{References}

Ahmad, M. B., Ali, H. F., Malik, M. S., Humayun, A. A., \& Ahmad, S. (2019). Factors Affecting Impulsive Buying Behavior with mediating role of Positive Mood: An Empirical Study. European Online Journal of Natural and Social Sciences, 8(1), pp17.

Alexander, B., Bain, J.K. (2016). Small store design and marketing effects: Experiential developments in SME fashion pop-up store strategies. In Mcintyre, C., Melewar, T.C., Dennis, C. (Eds.), Multi-channel marketing, branding, and retail design: New challenges and opportunities, (pp. 163-192). UK: Emerald Group Publishing Limited.

Ali, H. F., \& Sohail, M. The Impact of Change in Consumer Taste and Product Innovation on Sales Volumes of Consumer Goods.

Bakewell, C., \& Mitchell, V. W. (2003). Generation Y female consumer decision-making styles. International Journal of Retail \& Distribution Management, 31(2), 95-106.

Bala, A., Munoz, P., Rieradevall, J., \& Ysern, P. (2008). Experiences with greening suppliers: The universidad autonomy de Barcelona. Journal of Cleaner Production, 16(15), 1610-1619.

Brosdahl, D. J., \& Carpenter, J. M. (2011). Shopping orientations of US males: A generational cohort comparison. Journal of Retailing and Consumer Services, 18(6), 548-554.

Burns, D. J. (2011). Consumer decision-making styles: Relationships with consumer alienation. Journal of Business and Retail Management Research, 6(1).

Cataldi, C., Dickson, M., Grover, C., (2010). Slow fashion: Tailoring a strategic approach towards sustainability.

Centre for Economics and Business Research (2015). Britain's pop-up retail economy.

Chen, W. C., \& Fiore, A. M. (2017). Factors affecting Taiwanese consumers' responses toward pop-up retail. Journal of Marketing and Logistics, 29(2), 370-392.

Clark, H., (2008). Slow fashion an oxymoron or a promise for the future. Fashion Theory, $12(4), 427-446$.

Cui, Y., Trent, E. S., Sullivan, P. M., \& Matiru, G. N. (2003). Cause-related marketing: How generation $\mathrm{Y}$ responds. International Journal of Retail \& Distribution Management, 31(6), 310-320.

Ferreri, M., (2016). Pop-up shops as interruptions in (post) recessional London. In Jordan, S.,

Lindner, C. (Eds.). Cities interrupted. Visual cultures and urban space (pp. 141-156). UK: Bloomsbury.

Fishbein, M., \& Ajzen, I., (1975). Belief, Attitude, Intention and Behavior: An introduction to theory and research. Addison-Wesley.

Fletcher, K., (2010). Slow fashion: An invitation for system change. Journal of Fashion Practice, 2.

Goldsmith, R. E., Moore, M. A., \& Beaudoin, P. (1999). Fashion innovativeness and selfconcept: A replication. Journal of Product \& Brand Management, 8(1), 7-18.

Gordon, K.T. (2004). Give it a go: A hands-on approach to marketing your product could be just the thing to win customers. International Journal of Retail \& Distribution Management, 38(2), 133-154.

Grant, I. J., \& Stephen, G. R. (2005). Buying behavior of teenage girls and key societal communicating factors influencing their purchasing of fashion clothing. Journal of Fashion Marketing and Management, 9(4), 450-467.

Grewal, D., Roggeveen, A. L., \& Nordfält, J. (2017). The future of retailing. Journal of Retailing, 93(1), 1-6. 
Hair Jr., Joseph F., Black, William C., Babin, Barry C., Dan Rolph E. Anderson (2010). Multivariate Data Analysis. New Jersey: Pearson Prentice Hall.

Huffelen, W. (2016). Why pop-up stores are great for millennials. Go pop-up.

Krejcie, R. V., \& Morgan, D. W. (1970). Determining sample size for research activities. Journal of Educational and Psychological Measurement, 30, 607-610.

Lissitsa, S., \& Kol, O. (2016). Generation X vs. Generation Y-A decade of online shopping. Journal of Retailing and Consumer Services, 31, 304-312.

Malhotra, N. K. (1988). Self-concept and product choice: An integrated perspective. Journal of Economic Psychology, 9(1), 1-28.

Martin, C. A., \& Turley, L. W. (2004). Malls and consumption motivation: An exploratory examination of older Generation Y consumers. International Journal of Retail \& Distribution Management, 32(10), 464-475.

McColl, J., Canning, C., McBride, L., Nobbs, K., Shearer, L., (2013). It's vintage darling: An exploration of vintage fashion retailing. Journal of the Textile Institute, 104 (2), 140150.

Meister, J. C., \& Willyerd, K. (2010). Mentoring millennials. Journal of Harvard Business Review, 88(5), 68-72.

Morton, L. P. (2002). Targeting generation Y. Public Relations Quarterly, 47(2), 46.

Niehm, L. S., Fiore, A. M., Jeong, M., \& Kim, H. J. (2007). Pop-Up retail's acceptability as an innovative business strategy and enhancer of the consumer shopping experience. Journal of Shopping Center Research, 13(2), 1-30.

Onkvisit, S., \& Shaw, J. (1987). Self-concept and image congruence: Some research and managerial implications. Journal of Consumer Marketing, 4(1), 13-23.

Pomodoro, S. (2013). Temporary retail in fashion system: An explorative study. Journal of Fashion Marketing and Management, 17(3), 341-352.

Ryu, J. S. (2011). Consumer attitudes and shopping intentions toward pop-up fashion stores. Journal of Global Fashion Marketing, 2(3), 139-147.

Rehman, Z., Ali, H. F., Syed, A., Khan, M. A., \& Ali, R. (2018). Factors Effecting Consumer Trust in Online Purchases. International Journal of Global Sustainability, 2(1), 56-73.

Solomon, M.R. (1996). Consumer behavior: Buying, having and being, Englewood Cliffs: Prentice Hall.

Sproles, G. B., \& Kendall, E. L. (1986). A methodology for profiling consumers' decision-making styles. Journal of Consumer Affairs, 20(2), 267-279.

The Coca-Cola Retailing Research Council. (2010). Retailing in emergent markets: Strategic foundations and best practices the concept of retail personality. Journal of Business Research, 29, 101-109.

The Department for Communities and Local Government (2013). New opportunities for sustainable growth and development through the reuse of existing buildings.

Wolburg, J. M., \& Pokrywczynski, J. (2001). A psychographic analysis of Generation Y college students. Journal of Advertising Research, 41(5), 33-52.

Zhang, B., \& Kim, J. H. (2013). Luxury fashion consumption in China: Factors affecting attitude and purchase intent. Journal of Retailing and Consumer Services, 20(1), 6879.

Ziehl, M., Osswald, S., (2015). Practices in second hand spaces. Journal of Ephemera, 15(1), 263-276. 
Pakistan Journal of Humanities and Social Sciences, 7(1), 2019

\section{Appendix}

Table A1: Correlation Matrix

\begin{tabular}{|c|c|c|c|}
\hline & 1 & 2 & 3 \\
\hline ATPU & 1 & & \\
\hline YBB & $.670^{* *}$ & 1 & 1 \\
\hline FI & $.543^{* *}$ & $.546^{* *}$ & \\
\hline **. Correlation is significant at the 0.01 level (2-tailed).
\end{tabular}

Figure A1: Confirmatory Factor Analysis:

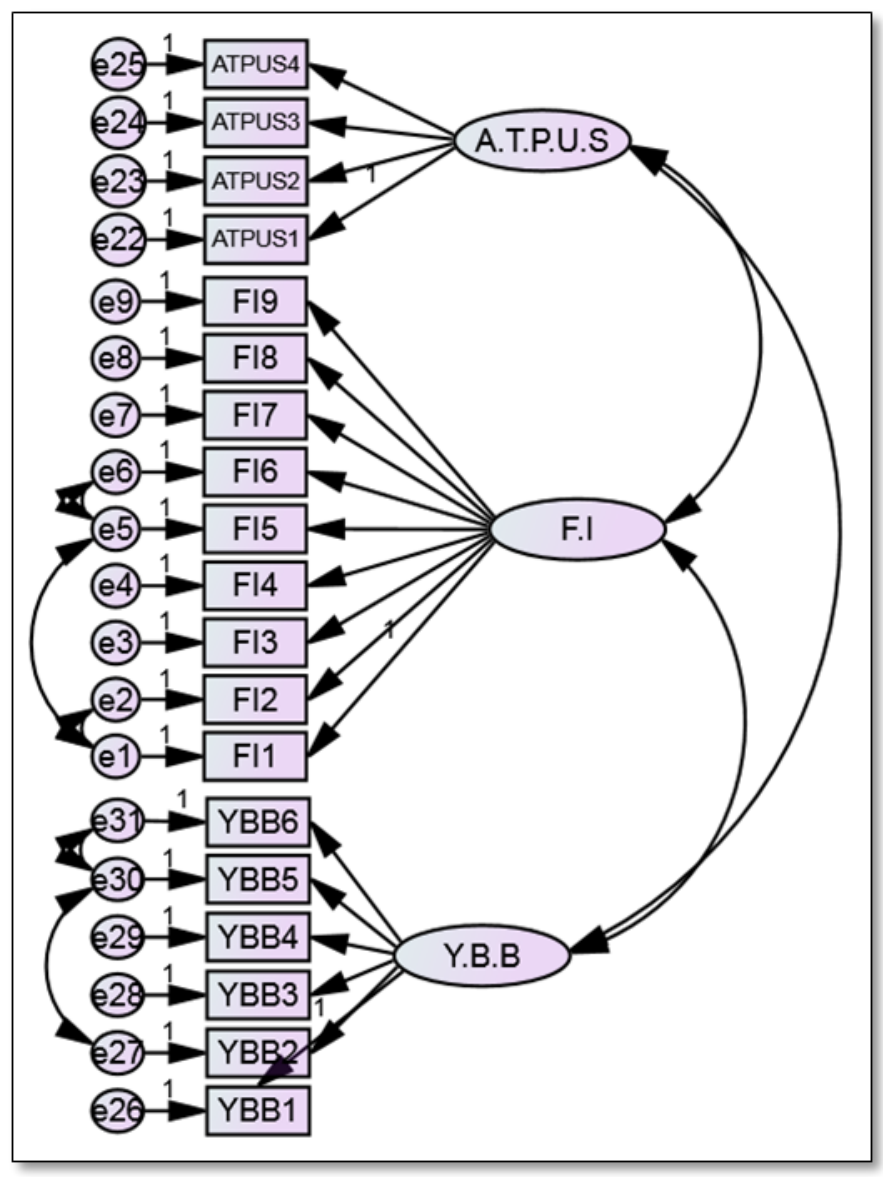

Table A2: Standardized Regression Weights: (Group number 1 - Default model)

\begin{tabular}{|l|l|l|l|}
\hline & & & Estimate \\
\hline FI1 & $<---$ & F.I & .475 \\
\hline FI2 & $<---$ & F.I & .572 \\
\hline FI3 & $<---$ & F.I & .640 \\
\hline FI4 & $<---$ & F.I & .384 \\
\hline FI5 & $<---$ & F.I & .569 \\
\hline FI6 & $<---$ & F.I & .610 \\
\hline
\end{tabular}




\begin{tabular}{|l|l|l|l|}
\hline & & & Estimate \\
\hline FI7 & $<---$ & F.I & .717 \\
\hline FI8 & $<---$ & F.I & .669 \\
\hline FI9 & $<---$ & F.I & .669 \\
\hline ATPUS1 & $<---$ & A.T.P.U.S & .787 \\
\hline ATPUS2 & $<---$ & A.T.P.U.S & .816 \\
\hline ATPUS3 & $<---$ & A.T.P.U.S & .736 \\
\hline ATPUS4 & $<---$ & A.T.P.U.S & .687 \\
\hline YBB1 & $<---$ & Y.B.B & .753 \\
\hline YBB2 & $<---$ & Y.B.B & .768 \\
\hline YBB3 & $<---$ & Y.B.B & .718 \\
\hline YBB4 & $<---$ & Y.B.B & .693 \\
\hline YBB5 & $<---$ & Y.B.B & .676 \\
\hline YBB6 & $<---$ & Y.B.B & .546 \\
\hline & & & \\
\hline
\end{tabular}

Above table shows the values of standardized regression weight which is above 3 .

Table A3: Fitness Summary

\begin{tabular}{|c|c|c|}
\hline & Model Values & Threshold Values \\
\hline CMIN/DF & 1.600 & $<3$ \\
\hline CFI & .966 & $>.95$ \\
\hline GFI & .935 & $>.90$ \\
\hline AGFI & .914 & $>.85$ \\
\hline RMSEA & .042 & $<.08$ \\
\hline PCLOSE & .899 & Closer to 1 \\
\hline
\end{tabular}

Figure A2: Structural Equation Model

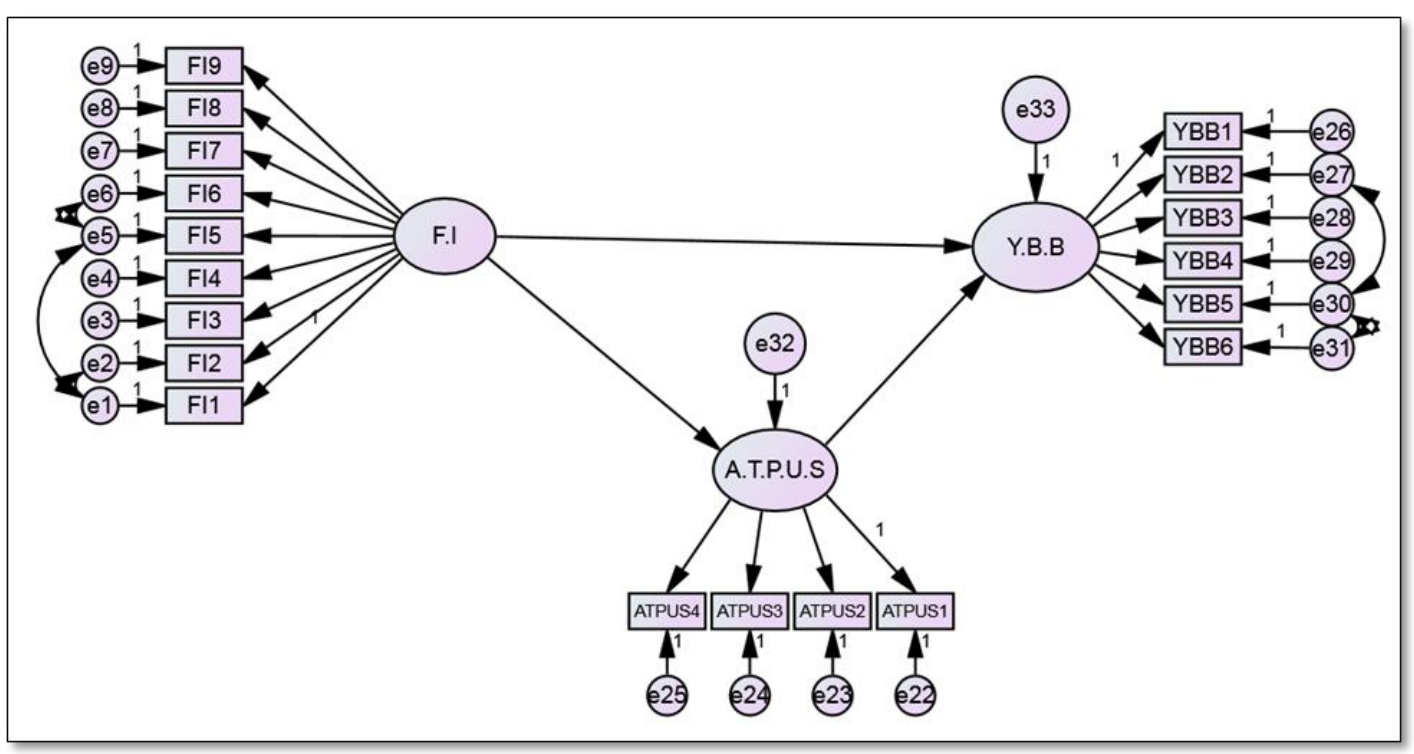


Pakistan Journal of Humanities and Social Sciences, 7(1), 2019

Table A4: Regression Weights: (Group number 1 - Default model)

\begin{tabular}{|l|l|l|l|l|}
\hline & & & Estimate & P \\
\hline A.T.P.U.S & $<---$ & F.I & 1.112 & $* * *$ \\
\hline Y.B.B & $<---$ & F.I & .367 & $* * *$ \\
\hline Y.B.B & $<---$ & A.T.P.U.S & .616 & $* * *$ \\
\hline
\end{tabular}

Above table shows the significance of the path at the level of 0.01 .

Figure A3: Bootstrapping Technique:

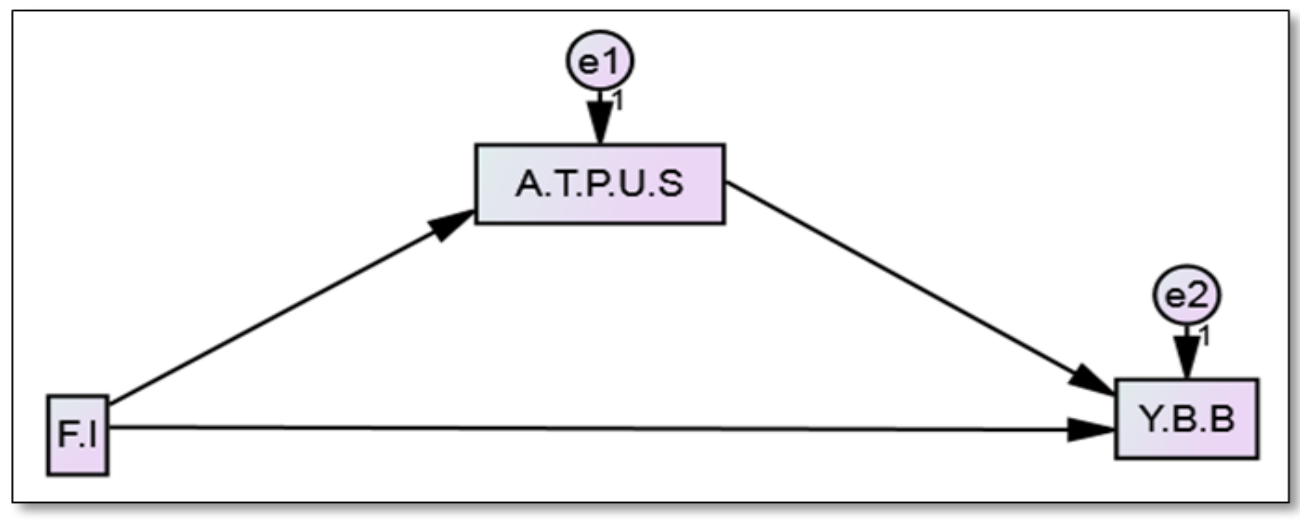

Table A5: Mediation Path:

\begin{tabular}{|l|l|l|l|l|}
\hline & $\begin{array}{l}\text { Direct Beta } \\
\text { Without } \\
\text { Mediation }\end{array}$ & $\begin{array}{l}\text { Direct } \\
\text { Beta With } \\
\text { Mediation }\end{array}$ & $\begin{array}{l}\text { Indirect } \\
\text { Beta }\end{array}$ & Results \\
\hline F.I-- $\rightarrow$ A.T.P.U.S-- $\rightarrow$ Y.B.B & $.367 * * *$ & $.261^{* * *}$ & $.487 * * *$ & $\begin{array}{l}\text { Partial } \\
\text { Mediation }\end{array}$ \\
\hline
\end{tabular}

